\title{
SINKRONISASI KEBIJAKAN HONORARIUM STANDAR BIAYA DALAM KERANGKA SINGLE REMUNERASI PENGANGGARAN BERBASIS KINERJA
}

\author{
Achmad Fauzan Sirat
}

Email: af.sirat05@gmail.com

\section{PENDAHULUAN}

\subsection{Latar Belakang}

Penganggaran berbasis kinerja lahir dari suatu keinginan bahwa menghubungkan antara alokasi dengan kinerja pemerintah yang didanai. Penganggaran berbasis kinerja, dilain pihak, memiliki sisi-sisi lain sebagai konsekuensi dari suatu pilihan sistem. Salah satu konsekuensi ini adalah pilihan dalam penggajian/kompensasi berdasarkan kinerja.

Standar biaya sebagai salah satu instrumen penganggaran berbasis kinerja memiliki peran penting dalam praktik penganggaran di Indonesia. Sebagai sebuah instrumen, standar biaya menjadi kunci efisiensi baik dalam rangka alokasi dan pelaksanaan anggaran. Namun demikian, aspek efisiensi dari sebuah standar biaya tersebut perlu untuk selalu ditandingkan dengan efektifitas pelaksanaan kegiatan yang dialokasikan. Dengan kata lain, sebagai sebuah pilar standar biaya memiliki dua sisi pertimbangan dalam penyusunannya yakni efisiensi sebagai pertimbangan utama dan efektifitas sebagai pertimbangan penyeimbang mengingat alokasi efisien bukan berarti suatu pelaksanaan pekerjaan tidak dapat berjalan efektif dalam menunjang pencapaian kinerja.

Berkenaan dengan sistem penggajian, diskusi hangat terjadi mengenai demarkasi antara honorarium sebagai produk dari standar biaya dan remunerasi sebagai bentuk penggajian kepada pegawai pemerintah. Saat kebijakan remunerasi digulirkan sejak tahun 2007 terdapat semangat menghapuskan praktik pemberian honor yang tersebar dalam beberapa kegiatan dan dimasukkan dalam suatu tatanan penghasilan terintegrasi, dikenal sebagai single remuneration system. Hal ini, disadari ataupun tidak, sejalan dengan prinsip Unified Budget yang mengitegrasikan pekerjaan proyek dalam satu managemen dengan pekerjaan rutin. Namun demikian, dalam praktiknya masih timbul beberapa honorarium disamping pemberian remunerasi. Bahkan demarkasi antara biaya honor dan remunerasi menjadi tidak terang dan dirasa cenderung overlap. Kondisi ini ditimbulkan dari kurangnya keberadaan kriteria bagaimana suatu kegiatan membutuhkan tambahan honorarium atau tidak.

\subsection{Rumusan Masalah}

Berdasarkan uraian diatas, sinkronisasi dari kebijakan honorarium perlu dilakukan 
dengan remunerasi dan agar menjadi komprehensif harus dimulai dari pembuatan kriteria. Dalam membuat kriteria perlu pemetaan mengenai kegiatan dan kajian mendalam mengenai aspek-aspek apa yang mempengaruhi sehingga dapat dikelompokkan dengan baik.

\subsection{Tujuan}

a. Apa perbedaan antara Honorarium dan Remunerasi?

b. Aspek-aspek yang mempengaruhi/perlu dipertimbangkan pemberian honor?

c. Bagaimana seharusnya pemberian honor dipetakan dan dikelompokkan?

d. Apakah seharusnya kriteria-kriteria dapat ditetapkan sebagai patokan kebijakan honorarium?

\section{METODOLOGI PENELITIAN}

Kajian ini berupa kajian eksplorasi berkenaan dengan kerangka kebijakan honorarium. Kajian eksplorasi ini bagian dari kajian kualitatif yang mencoba merangkai suatu kerangka kerja menilai kelayakan suatu honor atau setidaknya pengelompokannya. Kajian dilakukan dengan melakukan kajian pustaka dari referensi ilmiah yang bereputasi dan kerangka peraturan yang sudah diaplikasikan saat ini.

\section{LANDASAN TEORI}

\subsection{Performance-Based Compensation vs Seniority-Based Compensation}

Performance-based compensation menjadi topik yang sangat hangat sejalan dengan meningkatkan pemberlakuan prinsip-prinsip berbasis kinerja yang diterapkan dalam birokrasi akhir-akhir ini. Dalam beberapa kajian disebutkan bahwa pada dasarnya terdapat beberapa pertimbangan dalam melakukan performance-based compensation tersebut terutama dalam menarik talenta terbaik untuk bekerja di tempat tertentu, terutama pada bidang pemerintahan (Beth J. Asch 2015). Terlebih lagi dalam kajian lain disebutkan bahwa adanya hubungan yang sangat kuat antara kompensasi yang didasarkan oleh kinerja dengan productivitas kerjanya (Paarsch adn Shearer 1999, 2000: Lazaer 2000; Haley 2003; Badiera Barankay, and Rasul 2005, 2007). Namun demikian disisi lain pendekatan ini memiliki dampak lain yang merupakan konsekuensi dari pilihan kebijakan dimaksud yang berujung pada hasil yang sebaliknya. Konsekuensi tersebut terjadi karena sulitnya pengukuran kinerja individu pegawai, kehadiran tujuan perusahaan yang berbagai macam, tarikan atas pengambilan keputusan dengan berbagai dimensi, serta adanya kebutuhan yang bervariasi atas kinerja organisasi.

\section{Gambar 1. Kompensasi trade off antara kinerja dan pengalaman (deffered compensation)}

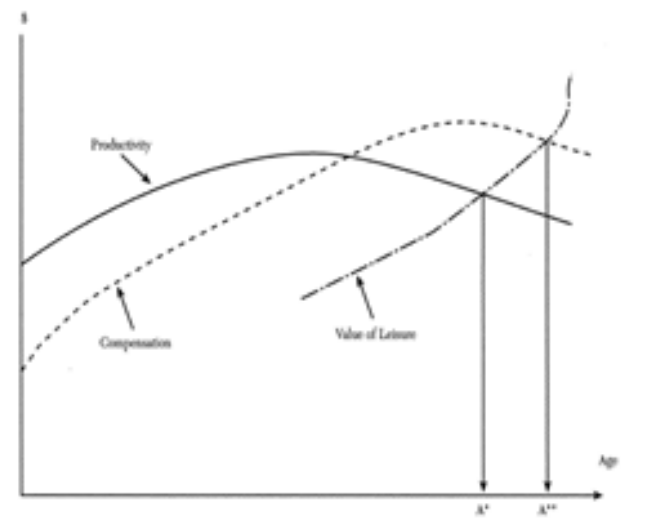

Pada dasarnya terdapat dua arus utama sistem kompensasi yang dipakai dan 
sering diulas dalam beberapa literature, yakni performance-based compensation dan seniority based compansation. Secara konsepsi,

performance-based compensation sangat berbeda dengan seniority based compansation. Penjelasan sederhana dapat merujuk pada gambar diatas. Pendekatan Performance-based Compensation akan membawa pembayaran upah pada level yang sama dengan kinerja yang dicapai. Sedangkan pada seniority-based compensation upah yang diberikan akan lebih rendah dibandingkan kinerja yang dicapai namun pada seiring dengan berjalannya waktu (senioritas) tingkat upah akan mendekati tingkat kinerja dimana pada titik tertentu akan akan melewati tingkat kinerja tersebut.

Kedua konsep tersebut memiliki keunggulan dan kelemahan masingmasing, dimana performance-based compensation mengedepankan current/immediate output sedangkan seniority-based compensation mengedepankan steadiness atau keberlangsungan. Gambar diatas menjelaskan juga mengenai fenomena yang dikenal dengan sebutan "deffered compensation" dimana surplus kinerja akan dikompensasikan dengan defisit kinerja dikemudian hari. Berkenaan dengan hal tersebut, perbedaan mendasar berkenaan dengan dua konsepsi tersebut adalah bagaimana kedua konsep tersebut menangani isu loyalitas dan kestabilan pendapatan bagi sebuah individu.

Hal yang sangat menarik berkenaan dengan pay-for-performance adalah bagaimana konsep ini dapat menggiring prilaku pekerja kepada hal yang menjadi indikator utama dalam penentuan besaran kompensasinya. Shingo Takahashi et.al (2014) menyatakan bahwa para peneliti ilmu sosial telah mengenal bahwa kontrak yang hanya berdasarkan satu indikator kinerja yang bisa diidentifikasi cenderung menghasilkan respon yang tidak semestinya. Sebagai contoh jika salesman dihargai berdasarkan jumlah penjualannya, maka dia akan lebih berfokus pada pekerjaan tersebut tanpa memperhatikan bahwa salesman tersebut memiliki tugas lain yakni menchoaching juniornya. Oleh karena itu, dalam beberapa hal besaran kompensasi yang dikaitkan dengan kinerja harus dibuat dalam proporsi yang tepat. Dengan demikian konsepsi pay-for-performance memiliki prasyarat: yakni rumusan kinerja yang tepat (dengan multi indikator, jika memungkinkan) dan besaran kompensasi yang berkaitan dengan kinerja harus dibuat tidak terlalu jauh (dalam berbagai referensi $20 \%$ atas besaran kompensasi).

Khusus hal yang terakhir, Lazaer (2000) menyatakan bahwa praktik dalam sektor privat mengindikasikan pemberian kompensasi lebih sering tidak secara explisit terkait dengan indikator kinerja tertentu, misalnya tingkat penjualan. Namun lebih pada indikator yang lebih jelas seperti jumlah jam kerja. Dari sisi besaran atau jumlah yang dikaitkan dengan kinerja, menurut Parent (1999) hanya berkisar 9.4 persen dari semua pembayaran dibayarkan berdasarkan kinerja individu seperti tingkat penjualan, dan 14.2 persen dibayar berupa bonus. Bahkan dalam beberapa kajian diindikasikan bahwa disparitas pendapatan atas top performance dan the lowest tidak begitu signifikan (Medoff and 
Abraham, 1980; Baker, jensen, and Murphy, 1988).

Hal yang menjadi simpulan dari poin ini setidaknya ada ketiga hal. Pertama adalah tambahan penghasilan yang dikaitkan dengan suatu kinerja merupakan praktik yang lumrah berkenaan dengan pemberian kompensasi kepada pegawai. Hal kedua adalah bahwa tambahan tersebut dapat menjadi pemicu kenaikan kinerja dan sekaligus penurunan atas kinerja, mengingat ada tidaknya indikator yang cukup tepat berkenaan dengan pemberian kompensasi tersebut. Terakhir adalah bagaimana besaran tambahan tersebut tidak terlampau jauh dibandingkan dengan kompensasi dasarnya dan diantara rekan sejawat.

\subsection{Definisi Berkenaan dengan kompensasi bagi pegawai}

Sebelum membahas lebih jauh, berikut disampaikan berbagai perspektif mengenai sistem pemberian kompensasi dari suatu pekerjaan.

\section{a) Gaji (Payroll) vs tunjangan (fringe

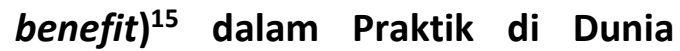 Privat}

Kompensasi bagi pegawai terdiri dapat berupa gaji (payroll) maupun tunjangan (fringe benefit). Pada dasarnya gaji dan tunjangan merupakan manfaat yang didapat oleh karyawan atas jasa yang diberikan pada perusahaan yang memakai jasanya. Namun terdapat perbedaan antara keduanya, yakni Gaji adalah penghasilan utama sedangkan tunjangan (fringe benefit) merupakan tambahan penghasilan kepada pegawai. Sejalan

\footnotetext{
${ }^{15}$ Referensi utama: Payroll Accounting ,Acccounting Coach diakses pada tanggal $6 / 11 / 2015$
}

dengan hal tersebut Tohardi (2002) menyatakan bahwa pada dasarnya kompensasi itu dapat dibagi menjadi dua bagian: direct compensation dan indirect compensation.

Selanjutnya menurut Hariandja (2002) Kompensasi pelengkap merupakan salah satu bentuk pemberian kompensasi berupa penyediaan paket benefit dan program- program pelayanan karyawan, dengan maksud pokok untuk mempertahankan keberadaan karyawan sebagai anggota organisasi dalam jangka panjang. Dengan perkataan lain kompensasi pelengkap adalah upaya penciptaan kondisi dan lingkungan kerja yang menyenangkan dan tidak secara langsung berkaitan dengan prestasi kerja.

$$
\text { Jenis-Jenis }
$$

Gaji/Direct

\section{Compensation:}

1. Gaji/Upah: terminologi gaji atau upah biasanya merujuk pada penerimaan secara periodik yang menjadi dasar dari pengupahan, sedangkan gaji biasanya ditujukan untuk pembayaran pada bagian "white-collar" dan upah untuk "blue-collar".

2. Bonus \& Komisi: terminologi ini merupakan pembayaran tambahan yang berkaitan dengan suatu kinerja tertentu, misalnya target penjualan.

3. overtime pay/lembur: terminologi ini merujuk pada pembayaran atas kelebihan waktu yang dilakukan pekerja dalam menyelesaikan pekerjaannya. Pembayaran overtime tersebut pada dasarnya tidak menyeluruh dengan dua hal yang

http://www.accountingcoach.com/payrollaccounting/explanation/2 
menjadi dasar pertimbangan, yakni: tanggungjawabnya dan tingkat pembayarannya.

Jenis-Jenis Tunjangan Fringe

Benefit/Indirect Compensation

1. payroll taxes and costs

$\begin{array}{ll}\text { - } & \text { Social Security } \\ \text { - } & \text { Medicare } \\ \text { - } & \text { sederal income tax } \\ - & \text { state income tax } \\ -\quad \text { state unemployment tax } \\ \text { - federal unemployment tax } \\ \text { worker compensation insurance }\end{array}$

2. employer paid benefits

- holidays
- vacations
- sick days
- insurance (health, dental, vision,
life, disability)
- retirement plans
- profit-sharing plans

b) GFS Manual Definition ${ }^{16}$

Kompensasi pada pegawai adalah jumlah total remunerasi, baik dalam bentuk kas maupun natura, yang terutang pada seseorang dalam hubungan pemberi kerja dan pekerja sebagai kompensasi dari pekerjaan yang dilakukan pekerja dalam suatu period. Sejumlah yang dibayarkan tersebut merupakan pertukaran atas jasa karyawan baik tenaga kasar maupun intelektual yang dilibatkan dalam proses produksi yang terjadi dalam suatu unit organisasi. Namun demikian, dalam kategori ini tidak termasuk dalam kompensasi kepada karyawan yang diberikan pada pembentukan barang modal mengingat hal tersebut akan diperhitungkan sebagai biaya pokok pembentukan barang modal tersebut. Selain itu, kompensasi bagi karyawan juga dikecualikan dari suatu kegiatan dimana tidak ada hubungan pemberi kerja dan pekerja, seperti Kontraktor, dan selfemployed outworkers (pekerja lepas/bukan pegawai tetap).

Demarkasi atas kompensasi pada pegawai dan klasifikasi dengan tidak adanya hubungan pekerjaan dapat dijelaskan pada bagian dalam GFS Manual sebagai berikut:

- Kompensasi diberikan kepada pekerja yang bukan merupakan pegawai dari pemerintah/instansi tertentu harus dimasukkan sebagai bagian dari belanja barang

- Hubungan kerja terjadi saat terjadi suatu perjanjian, baik tertulis maupun tidak, formal maupun tidak, antara institusi dan individu, atas kesepakatan kedua belah pihak, dimana individu pekerja dimaksud bekerja dengan imbalan remunerasi baik dalam bentuk uang ataupun natura.

- Jika seseorang dikontrak untuk mengerjakan sebuah tugas yang spesifik, disarankan hal tersebut dilakukan secara tanpa adanya hubungan pekerja dan pemberi kerja, namun dibentuk dalam hubungan kontraktual antara institusi dan individu tersebut.

Sebuah indikasi apakah telah terjadi hubungan pekerja dengan pemberi kerja dapat dilakukan dengan menggunakan kaidah sebagai berikut:

\footnotetext{
${ }^{16}$ Government Finance Statistics manual 2014 Washington, DC: International Monetary Fund, 2014
} 
1. Ada tidaknya pengendalian baik untuk mengendalikan secara personal atau untuk mengarahkan bagaimana pekerjaan dilakukan;

2. apakah seorang pekerja membayar sendiri sosial contribution yang ada atau tidak.

3. Apakah seseorang mendapatkan benefit lain yang diberikan oleh pemberi kerja kepada pekerjanya (misalnya: tunjangan, fasilitas, pembayaran/tunjangan pajak dan lain sebagainya.)

Beberapa penggunaan barang atau jasa yang digunakan oleh pemerintah yang tidak masuk secara langsung dalam proses produksi namun dikonsumsi oleh pegawai dalam melaksanakan proses tersebut. Secara umum, ketika barang atau jasa digunakan oleh pegawai atas kemauan atau dalam penguasan waktu mereka untuk kepentingan/kebutuhan pribadi pegawai, barang atau jasa tersebut merupakan remunerasi in kind (dalam bentuk natura). Namun demikian, ketika penggunaan barang dan jas tersebut adalah suatu keharusan agar pegawai dapat melaksanakan tugasnya, maka hal tersebut akan diperhitugkan sebagai penggunaan barang dan jasa atau bukan bagian dari remunerasi. Contohnya:

1. Alat yang digunakan dalam pekerjaan

2. Pakaian atau alat lain yang konsumen scara umum tidak akan menggunakan/membeinya atau dipakai dan yang digunakan secara khusu pada saat melakukan kerja for example, protective clothing, overalls, or uniforms;

3. Jasa Akomodasi pada tempat kerja atau tempat sejenisya yang tidak dapat dimiliki oleh rumahtangga dimana pekerja menggunakannya: seperti barak, kabin, dormitori, huts dll.

4. Makanan khusus yang diberikan dan dibtuhkan secara khusus dalam suatu kondisi kerja tertentu, pada saat perjalanan dinas dan pada saat melakukan pekerjaan.

5. Perubahan fasilitas, kamar mandi dlsb yang dibutuhkan pada tempat kerja

6. Fasilitas pertolongan pertama, pemeriksaan kesehatan atau lainnya yang dibutuhkan pada pekerjaan.

Walaupun pegawai membelinya dan dilakukan penggantian atas pembeliaannya nanti, hal tersebut tetap masuk sebagai bagian dari penggunaan barang dan jasa, bukan sebagai gaji atau tunjangan dari pegawai.

Menurut GFS, kompensasi kepada pegawai baik dalam bentuk kas atau natura, diluar social contribution payable for employers, dapat berupa:

a. Gaji Dasar/Hutang Gaji yang dibayar secara periodik, termasuk pada yang dibayar atas dasar piece rate atau tunjangan khusus dari lembur atau pemberian tunjangan saat bekerja jauh dari domisili atau pada daerah berkecamuk atau berbahaya, tunjangan expatriaton saat bekerja jauh di luar negeri, dan lain sebagainya.

b. Tunjangan Tambahan (Supplementary allowances) yang dibayar secara reguler, contoh tunjangan perumahan, kecuali social benefit;

c. Gaji/Tunjangan lain pada pegawai yang pergi dalam waktu singkat, misalnya: liburan atau cuti;

d. Tunjangan tambahan tahunan, seperti bonus and "13th month" pay;

e. Bonus Ad hoc atau pembayaran khusus yang terhubung langsung dengan 
skema umum pemberian insentif dalam perusahaan;

f. Komisi, gratifikasi, dan tips yang diterima oleh pegawai: ini harus dimasukkan dalam pembayaran untuk layanan yang diberikan oleh unit mempekerjakan pekerja, bahkan ketika mereka dibayarkan langsung kepada karyawan oleh pihak ketiga. Mereka dengan demikian dianggap sebagai dibayar oleh pekerja kepada karyawan .

Hal ini tidak termasuk:

1. Penggantian perjalanan, relokasi, atau biaya terkait dibuat oleh karyawan ketika mereka mengambil pekerjaan baru atau diwajibkan oleh majikan mereka untuk memindahkan rumah mereka ke bagian berbeda negara atau ke negara lain

2. Penggantian biaya yang dikeluarkan oleh karyawan pada peralatan, perlengkapan, pakaian khusus, atau barang-barang lainnya yang diperlukan secara eksklusif, atau terutama, untuk memungkinkan mereka untuk melaksanakan pekerjaan mereka mengecualikan manfaat sosial dibayarkan oleh pemerintah kepada karyawan mereka dalam bentuk :

3. Anak, pasangan, keluarga, pendidikan, atau tunjangan lainnya sehubungan tanggungan

4. Pembayaran dilakukan pada full, atau dikurangi, tingkat upah atau gaji untuk pekerja absen dari pekerjaan karena sakit, luka karena kecelakaan, cuti hamil, etc. 10

5. pembayaran pesangon kepada pekerja atau korban mereka yang kehilangan pekerjaan mereka karena redundansi , ketidakmampuan, kematian, dll
Termasuk dalam jenis (natura):

1. Makanan dan minuman yang disediakan secara teratur, termasuk unsur subsidi dari kantin kantor (untuk alasan praktis, tidak perlu untuk membuat estimasi untuk makanan dan minuman yang dikonsumsi sebagai bagian dari aparat hiburan resmi atau selama perjalanan bisnis)

2. Pakaian atau alas kaki yang karyawan dapat memilih untuk memakai sering di luar tempat kerja dan di tempat kerja

3. layanan Perumahan atau akomodasi dari jenis yang dapat digunakan oleh semua anggota rumah tangga yang karyawan milik

4. Layanan kendaraan atau barang tahan lama lainnya disediakan untuk penggunaan pribadi karyawan

5. Barang dan jasa yang dihasilkan oleh majikan, seperti perjalanan gratis di pesawat terbang atau kereta api pemerintah

6. Olahraga, rekreasi, atau fasilitas liburan bagi karyawan dan keluarga mereka

7. Transportasi ke dan dari tempat kerja, gratis atau parkir bersubsidi, ketika dinyatakan harus

8. harus dibayar untuk

9. penitipan anak untuk anak-anak karyawan

10. Nilai dari bunga oleh majikan ketika mereka memberikan pinjaman kepada karyawan di dikurangi atau bahkan nol tingkat bunga untuk keperluan membeli rumah, kendaraan, furniture, atau barang atau jasa lainnya (jumlah ini juga dicatat sebagai piutang bunga seperti yang dijelaskan dalam ayat

11. Dalam kasus perusahaan publik, upah dan gaji dalam bentuk juga dapat 
mencakup saham bonus atau saham dibagikan kepada karyawan.

Kontribusi sosial dibayar oleh pengusaha untuk dana sosial keamanan, dana pensiun yang terkait dengan ketenagakerjaan, atau skema asuransi sosial tenaga kerja terkait lainnya untuk mendapatkan hak untuk benefit sosial bagi karyawan mereka.

\section{c) Honorarium}

Dalam pengertian yang didapat dari web wikipedia.org, honorarium adalah pembayaran ex-gratia (yaitu pembayaran yang dilakukan tanpa adanya keharusan atau kewajiban hukum dari yang memberikan) dibuat untuk seseorang atas jasanya sesuai kapasitasnya selaku relawan atau untuk jasa yang secara tradisi tidak diberikan pembayaran. Pembayaran seperti Ini digunakan oleh kelompokkelompok seperti sekolah atau klub olahraga untuk membayar pelatih untuk biaya mereka. Contoh lain termasuk pembayaran untuk pembicara tamu di sebuah konferensi untuk menutupi perjalanan , akomodasi, atau waktu persiapan mereka.

Dengan kata lain dari pengertian tersebut, kata honorarium mengacu pada pemberian sebagai bentuk penghargaan kepada seseorang mengingat biasanya hal yang dilakukan bukan sesuatu yang dibayar. Hal inilah yang melandasi bagaimana standar atas pemberian penghargaan tersebut tidak terdapat di pasar.

\subsection{Faktor-Faktor Yang Mempengaruhi Besarnya Kompensasi}

Organisasi atau perusahaan dalam setiap pemberian kompensasi kepada karyawan mempunyai beberapa faktor yang mempengaruhi pemberian kompensasi.

Menurut Tohardi (2002) faktor-faktor yang mempengaruhi besar kecilnya kompensasi antara lain adalah produktivitas, kemampuan untuk membayar, kesediaan untuk membayar, penawaran dan permintaan tenaga kerja, organisasi karyawan, dan peraturan perundangundangan. Senada dengan pendapat tersebut, Hasibuan (2003) menyebutkan faktor-faktor yang mempengaruhi besarnya kompensasi, antara lain sebagai berikut: Penawaran dan permintaan tenaga kerja, Kemampuan dan kesediaan perusahaan, Serikat buruh/Organisasi karyawan, Pemerintah dengan undangundang Keppres, Biaya hidup/Cost of living, Posisi jabatan karyawan, Pendidikan dan pengalaman kerja, Kondisi perekonomian nasional, dan Jenis dan sifat pekerjaan.

Berdasarkan pendapat diatas dapat disimpulkan bahwa posisi jabatan karyawan, jenis pekerjaan yang dilakukan dan kemampuan perusahaan tersebut untuk membayar merupakan faktor-faktor yang mempengaruhi besar kecilnya pemberian balas jasa dan kompensasi terhadap karyawan. Dalam konteks kebutuhan penyusunan standar biaya, selayaknya posisi dan jenis pekerjaan yang akan diberikan kompensasi menjadi perhatian dalam perumusan besaran. Namun demikian ada hal lain yang tidak kalah penting yakni bagaimana pemberi kerja (pemerintah) mampu membayar atas jasa yang diberikan tersebut. untuk itu, selain dari posisi penerima, pertimbangan dari sisi pemberi berupa ketersediaan dana (fiscal space) harus menjadi perhatian. 
Secara umum dari beberapa hal yang menjadi rujukan dalam kajian ini dapat ditarik beberapa kesimpulan yang dapat digunakan sebagai kerangka pikir dalam penetapan honor beserta besarannya. adapun beberapa kriteria yang perlu dilakukan sebagai berikut:

1. Pembuatan Klasifikasi Kompensasi Kepada Pegawai

2. Pengelompokan Kompensasi

3. Formulasi Penghitungan Besaran

4. Penentuan Besaran

Berkenaan dengan hal tersebut, proposal disampaikan sehubungan dengan penetapan klasifikasi yang akan menjadi kerangka pikir dalam kajian ini.

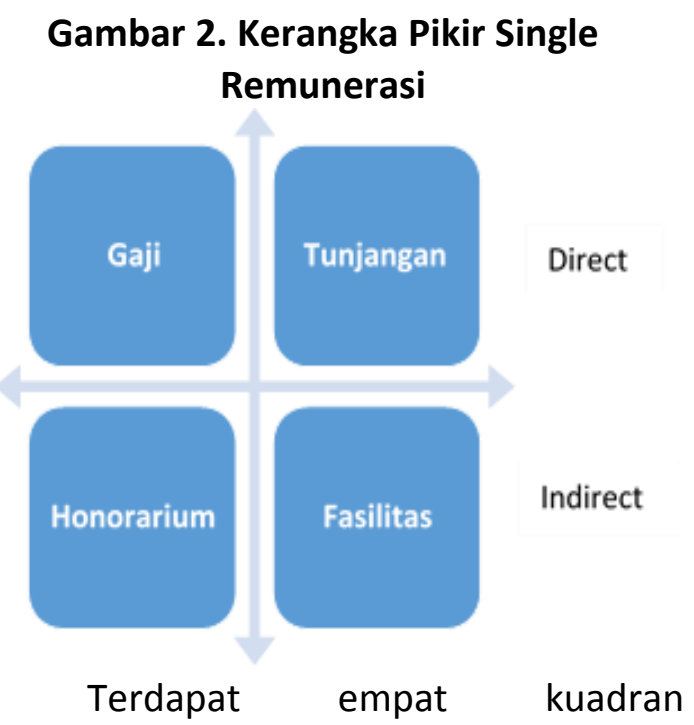

pemberian pemberi kerja kepada pegawai yang dapat dijadikan kerangka pikir dalam pengambilan kebijakan kompensasi. Adapun empat kuadran tersebut adalah sebagai berikut:

a. Gaji

Gaji merupakan pembayaran secara berkala kepada pegawai sebagai bentuk imbalan atas jasa yang diterima dari pegawai. Termasuk didalamnya adalah pembayaran overtime (lembur). Dasar filosofi dari gaji adalah segala sesuatu yang diperjanjikan pada saat perikatan kerja antara pekerja dan pemberi kerja. Dalam praktik, gaji tidak dibedakan baik dibayar harian, mingguan, bulanan. Hal yang menjadi pokok untuk mengidentifikasi gaji ada kesepakatan awal sebelumnya dan kompensasi apa yang menjadi imbalannya.

b. Tunjangan

Tunjangan merupakan tambahan penghasilan pegawai yang diberikan baik yang dibayarkan bersamaan dengan gaji ataupun tidak, misalnya tunjangan istri, tunjangan anak, tunjangan pajak, tunjangan jabatan termasuk juga bonus dan komisi. Tunjangan lebih bersifat optional. Pada umumnya tunjangan biasanya sejalan dan dibayarkan atas dasar gaji pegawai. Hal yang membedakan adalah proporsi antara keduanya yang secara umum menempatkan gaji pada tempat yang lebih besar.

c. Honorarium

Honorarium merupakan pembayaran yang diberikan kepada seseorang yang melaksanakan penugasan diluar kesepakatan kerja awal atau sebagai pembayaran atas pekerjaan yang dilakukan tanpa hubungan pekerja dan pemberi kerja. seperti keanggotaan dalam tim.

d. Fasilitas

Fasilitas merupakan pemberian sarana yang diberikan untuk kelancaran dalam pelaksanaan tugas. Pengertian sarana dalam hal ini adalah alat yang digunakan dalam pelaksanaan tugasnya. Dalam perkembangan, alat tersebut dapat diberikan dalam uang untuk kepentingan pelaksanaan tugas. 
Contoh dari fasilitas adalah kendaraan operasional, baju seragam, peralatan kerja dsb.

Konsekuensi dari pengelompokkan tersebut akan berakibat pada pendekatan yang perlu dilakukan berkenaan dengan perumusan kebijakan terkait dengan segala kompensasi kepada pegawai. Secara konsepsi penerapan standar biaya harus mempertimbangkan 3 aspek secara bersamaan, yakni:

a. Aspek fiskal

Setiap penetapan standar biaya akan mempengaruhi besaran biaya dialokasikan dari kemampuan keuangan daerah yang tersedia (kapasitas fiskal daerah). Oleh karena itu, penetapan standar biaya seefisien mungkin mengingat perubahan (kenaikan) standar biaya dapat mengurangi alokasi pada sektor yang lain.

b. Efektifitas

Setiap standar biaya yang ditetapkan harus diupayakan agar dapat membiayai kegiatan secara efektif. Adanya aspek fiskal tidak berarti kegiatan akan menjadi tidak terbiayai secara tuntas. Oleh karena itu, memastikan standar biaya ditetapkan pada angka rasional menjadi penting sebagai salah satu pertimbangan.

c. Efek Sistem

Penetapan standar biaya juga harus mempertimbangkan keberadaan satuan biaya lainnya, khususnya satuan biaya yang dasar perhitungannya atau jenisnya sama. Hal ini berarti juga pada saat terdapat perubahan disatu standar akan berefek secara relatif pada standar biaya lainnya.

\section{PEMBAHASAN}

\subsection{Kebijakan Honorarium Standar Biaya dari Tahun ke Tahun}

\subsubsection{Alokasi Belanja terkait dengan Penghasilan Pegawai}

Alokasi belanja pegawai dari tahun ke tahun meningkat, seiring dengan meningkatnya satuan gaji pokok sebanyak 6\% selama tahun 2009-2014 dan pemberian tunjangan kinerja pada kementerian/lembaga sejak tahun 2008. Peningkatan total gaji dan tunjangan yang melekat pada gaji sejak 10 tahun terakhir beranjak dengan laju peningkatan sebesar $13 \%$ selama lima tahun terakhir. Sejalan dengan hal tersebut peningkatan tunjangan kinerja juga stabil dengan laju peningkatan lebih tinggi dengan rata-rata sebesar 36\%.selama lima tahun. Hal yang menarik adalah penurunan alokasi untuk honor tetap (seperti honor penilik sekolah, vakasi dII) serta lembur yang secara tradisional dikenal dengan tingkat penurunan rata-rata $26 \%$ selama kurun waktu yang sama. Hal ini menunjukaan bahwa dalam satu sisi kebijakan remunerasi telah berhasil mengubah paradigma alokasi kedalam sistem penggajian tunggal. Namun disisi lain kerangka sistem penggajian tunggal mulai meninggalkan sistem overtime, jika diperlukan waktu lebih dalam melaksanakan pekerjaan. Selain itu sistem lama berkenaan dengan insentif tambahan juga mulai ditinggalkan. Hal ini tergambar secara ringkas dalam grafik 1. 


\section{Grafik 1. Komposisi Belanja Pegawai 2005-2015 (dalam juta)}

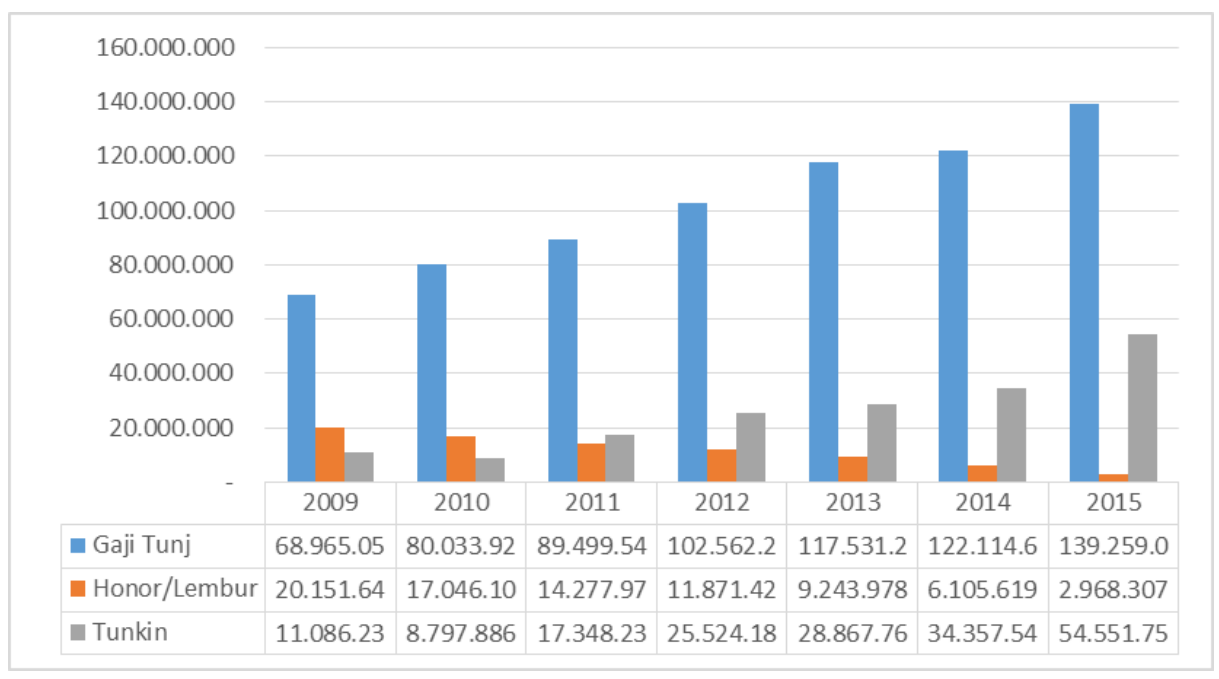

Grafik 2 menggambarkan bagaimana perilaku biaya birokrasi terkait dengan honor atau yang ada kaitannya dengan penghasilan pegawai selama kurun waktu 2008-2015. Dalam grafik tersebut, alokasi yang dimasukkan sebagai pertimbangan adalah berkenaan dengan honor tim Adhoc pengelola keuangan, honor tim terkait dengan output, dan honor narasumber. Alokasi honor pengelola keuangan meningkat sejalan dengan perkembangan jumlah satker dan ini merupakan mandat tetap atas pengelolaan keuangan yang ada. Perilaku biaya ini tidak mengkhawatirkan mengingat kontrol atas satuan biaya ini sudah sangat jelas baik dari sisi penerima maupun jumlah yang dapat diberikan. Dilain pihak, perkembangan honor terkait output kegiatan, yakni honor-honor tim pelaksana kegiatan, berkembang secara rata-rata $16 \%$ selama 5 tahun terakhir dengan nilai total tertinggi sampai dengan Rp. 13 trilyun. Hal ini masih cukup tinggi mengingat semangat penggajian secara tunggal serasa belum cukup efekif jika dilihat dari perkembangan atas pembayaran honor dimaksud.

Terakhir, berkenaan dengan pembayaran honor narasumber, data menunjukkan hal yang lebih menarik mengingat pertumbuhan alokasi mengalami kenaikan sebesar 33\% selama kurun waktu sama tol dan, secara proporsi, alokasi pada tahun 2015 sudah mencapai separuh dari alokasi honorarium tim pelaksana kegiatan. 


\section{Grafik 2. Honor Adhoc dan Belanja Honor lainnya (dalam juta)}

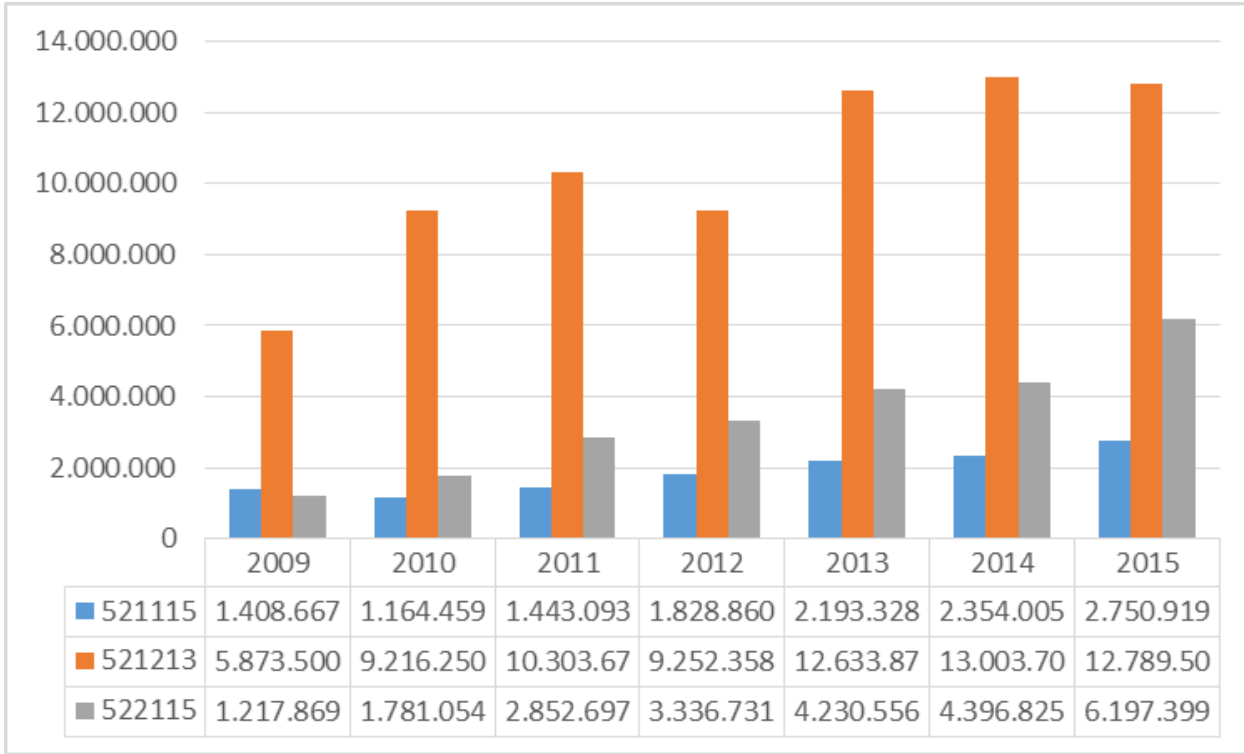

Dari deskripsi data tersebut diatas, dapat ditarik kesimpulan bahwa kebijakan remunerasi yang ada selama ini belum cukup efektif menekan laju pertumbuhan honor-honor adhoc yang selama ini berjalan. Hal ini dibuktikan dengan peningkatan atas gaji serta tunjangan dengan honor-honor adhoc lainnya. Kedua, penurunan honor tetap dan lembur yang selama ini menjadi penghasilan bersifat variable bagi pegawai diganti dengan alokasi honor adhoc. Ketiga, kebijakan honor adhoc dan honor lainnya sedikit banyak berpengaruh pada perilaku $\mathrm{K} / \mathrm{L}$ dalam mengalokasikan dananya, terutama untuk hal yang bersifat variabel.

\subsubsection{Bentuk Rumusan Kebijakan Honorarium}

Kebijakan Honorarium dalam standar biaya tertuang dalam tiga bentuk produk, yakni Peraturan Menteri Keuangan tentang Standar Biaya Masukan yang dikeluarkan tahunan, Peraturan Menteri Keuangan yang dikeluarkan tersendiri berkenaan dengan honorarium tertentu, dan Surat Persetujuan Standar
Biaya Masukan lainnya. Kebijakan ini terangkum dalam Peraturan Menteri Keuangan Nomor 71/MK.02/2013. Sedangkan terkait dengan gaji dan tunjangan (remunerasi) tertuang dalam produk kebijakan yang berbentuk Keputusan Presiden. Saat ini, pemrosesan PMK Standar Biaya dan SBM lainnya dilakukan pada Direktorat Sistem Penganggaran sedangkan Keppres mengenai gaji dan tunjangan diproses pada Direktorat Harmonisasi Peraturan Penganggaran.

Perkembangan rumusan kebijakan honorarium yang tercantum dalam Peraturan Menteri Keuangan tentang Standar Biaya Masukan terlihat sangat dinamis sebagai mana dapat dilihat pada tabel 1. Baik dari sisi pengelompokannya, besaran honorariumnya atau bahkan masuk tidaknya dalam sebuah pengaturan. Dinamika pengelompokan honor terlihat dari perubahan atas penempatan jenis honorariumnya dari tahun ke tahun. Dinamika juga berlaku pada uraian penjelasan atas honorarium dimaksud. Walaupun tidak sedinamis yang lain, 
besaran honorarium berubah pada

beberapa bagian secara parsial sehingga

perubahan terlihat beragam.

Tabel 1. Daftar Honor SBM dari Tahun ke Tahun

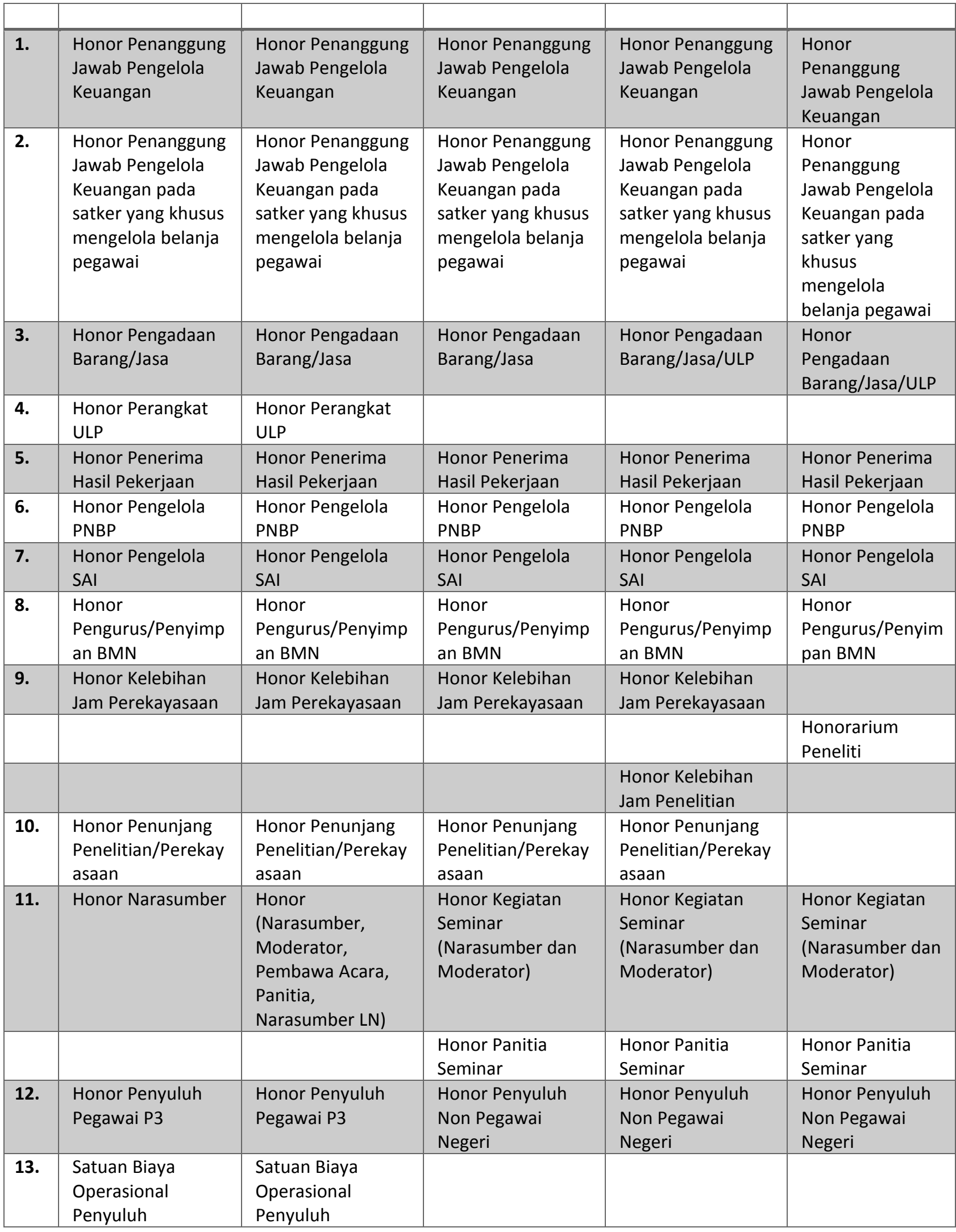




\begin{tabular}{|c|c|c|c|c|c|}
\hline 14. & Honor Rohaniwan & Honor Rohaniwan & Honor Rohaniwan & Honor Rohaniwan & \\
\hline 15. & $\begin{array}{l}\text { Honor Tim } \\
\text { Pelaksanan } \\
\text { Kegiatan dan } \\
\text { Sekretariat Tim } \\
\text { pelaksanan } \\
\text { Kegiatan }\end{array}$ & $\begin{array}{l}\text { Honor Tim } \\
\text { Pelaksanan } \\
\text { Kegiatan dan } \\
\text { Sekretariat Tim } \\
\text { pelaksanan } \\
\text { Kegiatan }\end{array}$ & $\begin{array}{l}\text { Honor Tim } \\
\text { Pelaksanan } \\
\text { Kegiatan dan } \\
\text { Sekretariat Tim } \\
\text { pelaksanan } \\
\text { Kegiatan }\end{array}$ & $\begin{array}{l}\text { Honor Tim } \\
\text { Pelaksanan } \\
\text { Kegiatan dan } \\
\text { Honor Sekretariat } \\
\text { Tim pelaksanan } \\
\text { Kegiatan }\end{array}$ & $\begin{array}{l}\text { Honor Tim } \\
\text { Pelaksanan } \\
\text { Kegiatan dan } \\
\text { Honor Sekretariat } \\
\text { Tim pelaksanan } \\
\text { Kegiatan }\end{array}$ \\
\hline 16. & $\begin{array}{l}\text { Honor Tim } \\
\text { Penyusun } \\
\text { Jurnal/Buletin/Maj } \\
\text { alah/Pengelola } \\
\text { Website }\end{array}$ & $\begin{array}{l}\text { Honor Tim } \\
\text { Penyusun } \\
\text { Jurnal/Buletin/Maj } \\
\text { alah/Pengelola } \\
\text { Website }\end{array}$ & $\begin{array}{l}\text { Honor Tim } \\
\text { Penyusun } \\
\text { Jurnal/Buletin/Maj } \\
\text { alah/Pengelola } \\
\text { Website }\end{array}$ & $\begin{array}{l}\text { Honor Tim } \\
\text { Penyusun } \\
\text { Jurnal/Buletin/Maj } \\
\text { alah/Pengelola } \\
\text { Website }\end{array}$ & $\begin{array}{l}\text { Honor Tim } \\
\text { Penyusun } \\
\text { Jurnal/Buletin/M } \\
\text { ajalah/Pengelola } \\
\text { Website }\end{array}$ \\
\hline \multirow[t]{3}{*}{17.} & $\begin{array}{l}\text { Honor } \\
\text { Penyelenggaran } \\
\text { Sidang } \\
\text { Internasional }\end{array}$ & $\begin{array}{l}\text { Honor } \\
\text { Penyelenggaran } \\
\text { Sidang } \\
\text { Internasional }\end{array}$ & $\begin{array}{l}\text { Honor } \\
\text { Penyelenggaraan } \\
\text { Sidang } \\
\text { Internasional }\end{array}$ & $\begin{array}{l}\text { Honor } \\
\text { Penyelenggaraan } \\
\text { Sidang } \\
\text { Internasional }\end{array}$ & $\begin{array}{l}\text { Honor } \\
\text { Penyelenggaraan } \\
\text { Sidang } \\
\text { Internasional }\end{array}$ \\
\hline & & & $\begin{array}{l}\text { Honor } \\
\text { Penyelenggaraan } \\
\text { Workshop } \\
\text { Internasional }\end{array}$ & $\begin{array}{l}\text { Honor } \\
\text { Penyelenggaraan } \\
\text { Workshop } \\
\text { Internasional }\end{array}$ & $\begin{array}{l}\text { Honor } \\
\text { Penyelenggaraan } \\
\text { Workshop } \\
\text { Internasional }\end{array}$ \\
\hline & & & $\begin{array}{l}\text { Biaya Narasumber } \\
\text { LN }\end{array}$ & $\begin{array}{l}\text { Biaya Narasumber } \\
\text { LN }\end{array}$ & $\begin{array}{l}\text { Biaya } \\
\text { Narasumber LN }\end{array}$ \\
\hline 18. & $\begin{array}{l}\text { Honor } \\
\text { Penyelenggaraan } \\
\text { Ujian dan Vakasi }\end{array}$ & $\begin{array}{l}\text { Vakasi dan Honor } \\
\text { Penyelenggaraan } \\
\text { Ujian }\end{array}$ & $\begin{array}{l}\text { Vakasi dan Honor } \\
\text { Penyelenggaraan } \\
\text { Ujian }\end{array}$ & $\begin{array}{l}\text { Vakasi dan Honor } \\
\text { Penyelenggaraan } \\
\text { Ujian }\end{array}$ & $\begin{array}{l}\text { Vakasi } \\
\text { Penyelenggaraan } \\
\text { Ujian }\end{array}$ \\
\hline 19. & $\begin{array}{l}\text { Honor } \\
\text { Penyelenggaraan } \\
\text { Kegiatan DIKLAT }\end{array}$ & $\begin{array}{l}\text { Honor Pengajar } \\
\text { DIKLAT }\end{array}$ & & & \\
\hline 20. & $\begin{array}{l}\text { Satuan Biaya Uang } \\
\text { Makan ASN }\end{array}$ & $\begin{array}{l}\text { Satuan Biaya Uang } \\
\text { Makan ASN }\end{array}$ & $\begin{array}{l}\text { Satuan Biaya Uang } \\
\text { Makan PNS }\end{array}$ & $\begin{array}{l}\text { Satuan Biaya Uang } \\
\text { Makan PNS }\end{array}$ & $\begin{array}{l}\text { Satuan Biaya } \\
\text { Uang Makan PNS }\end{array}$ \\
\hline 21. & $\begin{array}{l}\text { Satuan Biaya Uang } \\
\text { Lembur dan Uang } \\
\text { Makan Lembur }\end{array}$ & $\begin{array}{l}\text { Satuan Biaya Uang } \\
\text { Lembur dan Uang } \\
\text { Makan Lembur }\end{array}$ & $\begin{array}{l}\text { Satuan Biaya Uang } \\
\text { Lembur dan Uang } \\
\text { Makan Lembur }\end{array}$ & $\begin{array}{l}\text { Satuan Biaya Uang } \\
\text { Lembur dan Uang } \\
\text { Makan Lembur }\end{array}$ & $\begin{array}{l}\text { Satuan Biaya } \\
\text { Uang Lembur dan } \\
\text { Uang Makan } \\
\text { Lembur }\end{array}$ \\
\hline 22. & $\begin{array}{l}\text { Satuan Biaya Uang } \\
\text { Rapat dalam } \\
\text { Kantor }\end{array}$ & $\begin{array}{l}\text { Satuan Biaya Uang } \\
\text { Rapat dalam } \\
\text { Kantor }\end{array}$ & $\begin{array}{l}\text { Satuan Biaya Uang } \\
\text { Rapat dalam } \\
\text { Kantor }\end{array}$ & $\begin{array}{l}\text { Satuan Biaya Uang } \\
\text { Rapat dalam } \\
\text { Kantor }\end{array}$ & $\begin{array}{l}\text { Satuan Biaya } \\
\text { Uang Rapat } \\
\text { dalam Kantor }\end{array}$ \\
\hline 23. & $\begin{array}{l}\text { Satuan Biaya Uang } \\
\text { Saku Pemeriksaan } \\
\text { dalam lokasi } \\
\text { perkantoran yang } \\
\text { sama }\end{array}$ & $\begin{array}{l}\text { Satuan Biaya Uang } \\
\text { Saku Pemeriksaan } \\
\text { dalam lokasi } \\
\text { perkantoran yang } \\
\text { sama }\end{array}$ & & & \\
\hline 24. & $\begin{array}{l}\text { Honor Satpam, } \\
\text { pengemudi, } \\
\text { Petugas Kebersihan } \\
\text { dan Pramubakti } \\
\text { (per Prop) }\end{array}$ & $\begin{array}{l}\text { Honor Satpam, } \\
\text { pengemudi, } \\
\text { Petugas } \\
\text { Kebersihan dan } \\
\text { Pramubakti } \\
\text { (per Prop) }\end{array}$ & $\begin{array}{l}\text { Honor Satpam, } \\
\text { pengemudi, } \\
\text { Petugas } \\
\text { Kebersihan dan } \\
\text { Pramubakti } \\
\text { (per Prop) }\end{array}$ & $\begin{array}{l}\text { Honor Satpam, } \\
\text { pengemudi, } \\
\text { Petugas } \\
\text { Kebersihan dan } \\
\text { Pramubakti }\end{array}$ & $\begin{array}{l}\text { Honor Satpam, } \\
\text { pengemudi, } \\
\text { Petugas } \\
\text { Kebersihan dan } \\
\text { Pramubakti }\end{array}$ \\
\hline
\end{tabular}

Daftar tersebut diatas merupakan honorarium yang tercantum dalam PMK SBM dari tahun ke tahun. Jika dikelompokkan honor-honor tersebut terdiri dari: 
1. Honor terkait pejabat terkait pengelola keuangan/pejabat pengadaan/kebendaharaan;

2. Honor terkait penelitian (kelebihan penelitian/perekayasaan dan penunjang penelitian/perekayasaan)

3. Honor terkait dengan penyuluhan (honor dan biaya operasional)

4. Honor tim ad hoc (pelaksana kegiatan/jurnal/majalah/sidang internasional dll)

5. Honor Penyelenggaraan ujian dan vakasi

6. Honor terkait Lembur/Uang Makan Lembur

7. Honor terkait dengan pelaksanaan Rapat

8. Honor terkait dengan Biaya Pemeriksaan yang menjadi TUSI

9. Honor terkait dengan perikatan tenaga kontrak

(satpam/pengemudi/pramubakti/kebe rsihan)

Pada umumnya honorarium diformulasikan berdasarkan metode point factor. Metode ini meliputi identifikasi variabel yang mempengaruhi bobot masing-masing posisi dalam jabatan tertentu dan penentuan dasar perhitungan besaran. Variable yang diidentifikasi terdiri dari tanggung jawab, risiko pekerjaan, kompleksitas pekerjaan, pendidikan formal yang dibutuhkan dan pangkat/golong minimal yang dibutuhkan untuk menduduki jabatan tersebut. Kelima variabel tersebut nantinya akan menjadi indeks yang membedakan antara tingkat jabatan dalam kelompok jabatan tertentu. Sedangkan terkait dengan dasar perhitungan, besaran yang diacu adalah sama untuk satu kelompok jabatan tertentu. Besaran ini dapat berupa gaji pokok untuk golongan tertentu, tarif lembur dan lainnya.

Dari sekian banyak honor yang tercantum, honor pejabat terkait pengelolaan

keuangan/pengadaan/kebendaharaan diformulasikan secara bersamaan menggunakan metode point factor. Sedangkan honor lainnya diformulasikan secara terpisah. Dengan demikian, patut diduga bahwa konsistensi perhitungan yang bisa dijaga secara kesisteman tidak menyeluruh.

Selain kebijakan Honorarium yang dimasukkan dalam PMK Standar Biaya Masukan diatas, terdapat beberapa honorarium yang dikeluarkan dalam bentuk Standar Biaya Masukan Lainnya. Adapun kebijakan yang menjadi contoh dari bentuk ini antara lain: honorarium dokter internship, pemberian uang pengamanan bagi petugas Bea dan Cukai. Kebijakan ini pada umumnya dikeluarkan dalam bentuk surat persetujuan Menteri Keuangan atas dasar usulan dari Kementerian/Lembaga namun demikian tidak menutup kemungkinan kebijakan ini diangkat dalam bentuk satu Peraturan Menteri tersendiri. Bahkan dalam beberapa hal, kebijakan honorarium yang dikeluarkan dalam bentuk surat persetujuan diintegrasikan dengan kebijakan umum standar biaya masukan dalam Peraturan Menteri. Perumusan SBML tersebut terkadang didasarkan atas perhitungan mandiri pengusul dengan konfirmasi lebih lanjut atas perhitungan yang ada.

Hal tersebut diatas menghasilkan setidaknya dua kondisi yang menjadi risiko dalam perumusannya, yakni: konsistensi atas klasifikasi dan konsistensi atas dasar 
perhitungan. Pada akhirnya, risiko terberat adalah kebijakan honorarium akan mengalami penurunan kredibiltas dalam perumusannya. Untuk mengurangi risiko tersebut, suatu kriteria yang dapat menjaga konsistensi atas dua kondisi dibutuhkan. Klasifikasi dapat dikaitkan dengan konsepsi pemberian kompensasi atas pekerjaan secara komprehensif. Sedangkan dasar perhitungan besaran akan mengikuti metode yang menjadi dasar penghitungan pada setiap klasifikasi yang ada.

\subsubsection{Kompleksitas Rumusan Kebijakan Honorarium}

Sebagai konsekuensi atas bentuk kebijakan yang berbeda beda, kompleksitas atas Rumusan Kebijakan Honorarium pun tidak sama. Hal ini dapat dilihat dari setidaknya dalam tiga indikator, yakni: baru tidaknya rumusan honorarium, waktu penyelesaian, dan efek penetapan. Rumusan kebijakan baru akan berbeda dengan kebijakan honorarium yang sudah ada. Hal ini dikarenakan rumusan kebijakan baru harus mempertimbangkan dasar perhitungan dari awal, sedangkan kebijakan yang sudah ada biasanya sudah lebih stabil dari cara perhitungan dan halhal lain yang menjadi pertimbangan.

Indikator berikutnya adalah berkenaan dengan waktu penyelesaian. Panjang pendeknya waktu penyelesaian rumusan kebijakan dapat mengindikasikan kompleksnya kebijakan yang akan diambil. Hal ini dapat terjadi karena luasnya ruang koordinasi, tidak adanya benchmark, dan kurangnya pengaturan yang akan menjadi dasar dari kebijakan.
Sedangkan berkenaan dengan indikator yang terakhir, efek dari penetapan merupakan akibat yang muncul setelah kebijakan ini digulirkan. Pada beberapa kebijakan, pertimbangan matang harus benar-benar dilakukan mengingat dapat saja efek berikutnya dari kebijakan tersebut adalah berkaitan dengan penyediaan alokasi dana pada dokumen anggaran. Sebagai contoh kenaikan $10 \%$ pada tarif uang makan PNS akan berefek bagi negara setidaknya tambahan dana $10 \%$ dari 4 juta pegawai.

Kompleksitas tersebut semakin menjadi kendala sekaligus tantangan mengingat belum ada kriteria yang disepakati dalam perumusan kebijakan lebih lanjut. Dilain pihak, kriteria standar untuk kebijakan honorarium perlu ada guna adanya kepastian penanganan. Untuk itu kesepakatan atas kriteria standar dalam perumusan kebijakan honorarium adalah sebuah kebutuhan mendasar dalam kerangka single remunerasi pada penerapan pengangaran berbasis kinerja.

\subsection{Usulan Formulasi Kebijakan Umum Honorarium Standar Biaya}

\subsubsection{Evaluasi Rumusan Kebijakan Honorarium}

Sebagaimana dibahas pada bab sebelumnya, gambaran perumusan kebijakan honorarium memiliki celah kebijakan yang perlu segera diisi. Adapun celah tersebut berkenaan dengan kriteria perumusan honorarium dalam kerangka single remunerasi. Kriteria tersebut akan memperjelas demarkasi antara kompensasi langsung (direct) dan tidak langsung (indirect) dalam satu kerangka kompensasi terhadap pegawai. 
Secara umum honor-honor tersebut jika diklasifikasikan dalam kerangka 4 kuadran menjadi sebagai berikut:

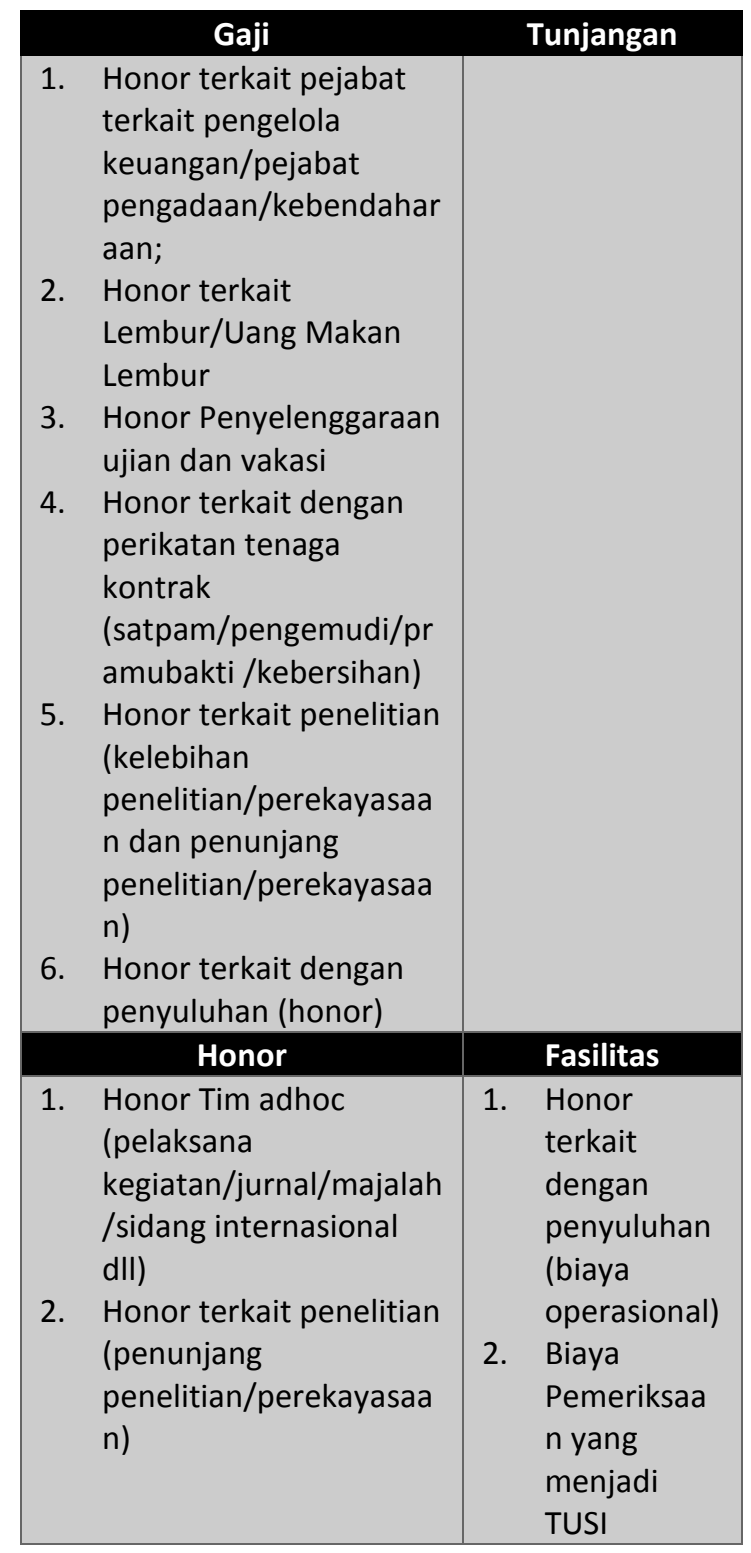

$\begin{array}{ccc}\text { Adapun } & \text { dasar } & \text { dalam } \\ \text { pengelompokan } & \text { tersebut } & \text { adalah }\end{array}$
sebagaimana diulas dalam definisi. Gaji merupakan pembayaran secara berkala kepada pegawai yang termasuk didalamnya pembayaran overtime. Tunjangan merupakan tambahan penghasilan yang pada prinsipnya bersifat optional. Honorarium adalah pembayaran atas penugasan yang berada diluar dari kesepakatan kerja awal, bersigat adhoc dan tidak terus menerus. Sedangkan fasilitas merupakan pemberian sarana yang diberikan untuk kelancaran dalam pelaksanaan tugas.

Termasuk dalam kelompok gaji adalah honor pejabat pengelola keuangan/pejabat pengadaan/kebendaharaan. lembur dan uang makan lembur, honor penyelenggaraan ujian dan vakasi, honor terkait dengan perikatan tenaga kontrak, honor terkait dengan penelitian, dan honor terkait dengan penyuluhan. Lembur/uang makan lembur dan penyelenggara ujian dan vakasi masuk dalam kategori pertama mengingat keduanya pada dasarnya semacam overtime atas pelaksanaan tugas. Lembur bagi pekerja kantor dan penyelenggaraan ujian/vakasi bagi pendidik merupakan pelaksanaan pekerjaan diluar jam operasional utama. Pekerja kantor akan bekerja diluar jam kerja, sedangkan untuk pendidik overtime terjadi pada saat diluar jam mengajar. Sedangkan honor yang diberikan pada pekerja dengan perikatan kontrak dan Penyuluh masuk pada kategori pertama karena hal inilah yang menjadi sejatinya penghasilan utama pekerja atas jasa yang diberikan.

Dalam kelompok tunjangan terdapat tidak terdapat dalam peraturan standar biaya masukan eksisting. Kelompok honor ini merupakan biasanya terkait dengan penggunaan tunjangan secara umum yang biasa dituangkan dalam peraturan lainnya.

Sebagaimana ketentuan pada dasarnya yang masuk dalam kategori ini adalah bagian penugasan diluar kesepakatan kerja awal (tugas tambahan). 
Honorarium yang bersifat ad-hoc ini dimasukkan dalam kategori honorarium karena pada dasarnya yang diberikan merupakan bagian yang tidak terdefinisikan pada saat perikatan pekerjaan.

Sedangkan untuk klasifikasi terakhir, honororium terdiri dari Honor terkait dengan penyuluhan (biaya operasional), dan Biaya Pemeriksaan yang menjadi TUSI. Beberapa pengaturan honor tersebut pada dasar merupakan fasilitas yang diberikan oleh negara dalam pelaksanaan tugasnya. Secara substansi pengaturan dimaksud tidak termasuk sebagai honor namun pemberian fasilitas dalam bentuk pertanggung-jawaban lumpsum. Hal ini sama halnya jika seorang pegawai diberikan uang transport pada saat tidak disediakan kendaraan dinas untuk menuju lokasi penugasan. Biaya operasional penyuluh dan biaya pemeriksaan yang menjadi TUSI pada dasarnya ada fasilitas yang diberikan negara.

\subsubsection{Usulan Formulasi Kebijakan Standar Biaya}

Sehubungan dengan hasil evaluasi diatas usulan formulasi kebijakan standar biaya akan berkisar dari pembedaan honor dan remunerasi dalam kerangka single remunerasi, aspek-aspek yang mempengaruhi, pengelompokkan atau kategorisasi pemberian honor dalam kerangka single remunerasi dan standardisasi kriteria pada tiap kelompok. Bahasan berikut adalah berkenaan dengan ke-empat faktor tersebut diatas.

http://nasional.tempo.co/read/news/2010/01/26/
1) Kerangka Single Remunerasi.

Kerangka Single Remunerasi adalah kerangka penghasilan dengan memperhitungkan semua penghasilan yang diterima oleh seorang pekerja, atau dengan kata lain dengan sudut pandang adalah pekerja sebagai sebuah individu yang dipekerjakan. Dalam sebuah artikel koran online, remunerasi merupakan prasyarat menuju single salary system yang diartikan bahwa seorang pegawai hanya mendapatkan gaji dan tunjangan tanpa perlu mengharapkan lagi honorhonor yang berkaitan dengan pelaksanaan tugasnya ${ }^{17}$. Untuk itu pertimbangan dalam formulasi kebijakan standar biaya harus memperhitungkan faktor tersebut.

Terdapat setidaknya empat hal yang perlu dilpertimbangkan dalam kerangka single remunerasi tersebut, yakni:

a. apakah suatu pekerjaan merupakan pekerjaan utama atau pekerjaan tambahan

b. seberapa banyak waktu yang dibutuhkan dalam melaksanakan satu tugas

c. seberapa besar porsi penghasilan tambahan dibandingkan penghasilan utama (gaji dan tunjangan) yang diterima

d. adakah duplikasi pemberian kompensasi atas pekerjaan antara pekerjaan utama dan pekerjaan tambahan

Keempat pertanyaan ini perlu menjadi standar dalam menilai apakah

063221589/kpk-single-salary-system-bisaditerapkan-pasca-remunerasi diakses 11/02/2016 
suatu usulan kebijakan masih dalam satu kerangka atau tidak. Pertanyaan pertama berkenaan dengan esensi perikaatan antara pemberi kerja dan pekerja yang secara alaminya tidak ada pemberi kerja yang memberi pekerjaan kepada pekerja untuk melakukan pekerjaan tambahan. Perlu diingat perspektif yang dipakai adalah pekerja tersebut. sehingga seandainya seseorang diangkat sebagai pramubakti dalam sebuah satker, bagi pekerja tersebut, itu adalah pekerjaan utama. Sehingga atas pekerjaan tersebut diperoleh imbalan atas jasanya berupa gaji.

Pertanyaan kedua berkenaan dengan pengujian bagaimana suatu pekerjaan merupakan pekerjaan tambahan atau tidak. Jika proporsi waktu pengerjaan pekerjaan tambahan lebih besar dibandingkan tugas utama, perlu dievaluasi yang mana yang pekerjaan tambahan.

Pertanyaan ketiga berkenaan dengan aspek psikologis dan keadilan antara tambahan pekerjaan dan tugas utama. Sebagaimana merujuk kondisi multitasking, secara psikologis pekerja akan cenderung mengerjakan apa yang lebih menguntungkan dari sisi personal. Dalam konteks ini, jika penghasilan untuk tugas tambahan atau tambahan penghasilan lebih besar maka pekerja akan cenderung memilih tugas tambahan tersebut mengingat rewardnya. Hal ini akan terlabih lagi jika reward yang diberikan bersifat variable terhadap pekerjaan. Secara konsepsi, lebih besar penghasilan tambahan dari pada penghasilan utama akan merusak konsep keadilan dalam penggajian.

Terakhir, pertanyaan berkenaan apakah atas penggajian utama sudah memperhitungkan pekerjaan tambahan dimaksud. Sejatinya jika pekerjaan tersebut masih terkait dengan pekerjaan utama dapat ditenggarai bahwa pekerjaan tersebut masih dalam jangkauan pekerjaan utama. Sebagai contoh, seorang petugas lalu lintas mengatur lalu lintas pada kondisi normal atau pada saat kondisi ada kecelakaan. Kondisi yang lebih membutuhkan penanganan tidak membuat pekerjaan tersebut menjadi pekerjaan tambahan, namun demikian mengingat dibutuhkan jam kerja lebih untuk penanganan maka ha tersebut diperlakukan sebagai lembur atau overtime dari normal time.

2) Aspek-aspek yang mempengaruhi besaran dan pemberian honorarium.

Terdapat banyak aspek yang mempengaruhi besaran dan pemberian honorarium. Secara prinsip, besaran honorarium tidak boleh lebih besar dari gaji dan tunjangan yang menjadi alasan seseorang dipekerjakan. Hal ini berdasarkan konsepsi multasking bahwa pekerja akan cenderung mengerjakan pekerjaan yang memberikan reward tinggi dan mengesampingkan kinerja yang unrewarded. Perilaku ini akan berakibat tidak baik secara keseluruhan organisasi. Hal yang kedua adalah perlu adanya level sesuai dengan tanggung jawab pekerjaan. Seorang superviser atau koordinator tidak bisa disamakan dengan subordinatnya, mengingat kompleksitas dan tanggung jawabnya berbeda secara hierarki. Untuk itu, besaran perlu memperhatikan hierarki tersebut. selain itu, faktor kompetensi juga harus dipertimbangkan dalam 
formulasi besaran sehingga top performer dengan middle performer berefek. Secara umum kompetensi bisa dilihat dari berbagai indikator, seperti pengalaman kerja, pendidikan, atau hasil evaluasi dari kinerja terdahulu.

Berkenaan bagaimana honorarium dapat diberikan, kebijakan selayaknya berfokus pada seberapa mungkin suatu pekerjaan dikategorikan sebagai tambahan yang tidak diperhitungkan dalam kegiatan pekerjaan utama. Dengan pengembangan dari empat pertanyaan sebagaimana disampaikan dalam subbab sebelumnya, perlu dibuat suatu kategori untuk kemudahan dan konsistensi kebijakan standar biaya, khususnya berkenaan dengan honorarium.

3) Kelompok honor dalam kerangka single remunerasi.

Sebagaimana beberapa kali diulas, pengelompokkan kebijakan standar biaya adalah sesuatu yang penting untuk formulasi kebijakan berikutnya. Sebagai usulan kerangka kebijakan single remunerasi utk formulasi kebijakan standar biaya, kelompok tersebut adalah sebagai berikut:

a. Gaji

Merupakan basis kompensasi yang diberikan dalam rekrutmen pekerja

b. Tunjangan

Merupakan opsi atas penghasilan dikaitkan dengan suatu kondisi tertentu

c. Honorarium

Merupakan tambahan penghasilan sebagaimana tambahan pekerjaan diluar tugas utama

d. Fasilitas
Merupakan alat, bahan, akomodasi atau biaya tambahan yang diberikan guna mendukung pelaksanaan pekerajaan

4) Standardisasi kriteria pada tiap kelompok.

Berkenaan dengan keempat kelompok kebijakan standar biaya dalam kerangka single remunerasi, perlu dibuat kriteria yang standar sebagai penjelas dari definisi. Adapun kriteria yang menjadi usulan adalah sebagai berikut:

a. Gaji

Sebagai basis kompensasi yang diberikan dalam rekrutmen pekerja maka kriteria yang perlu ada pada kategori ini adalah:

- Merupakan penghasilan utama atas suatu perikatan pekerja dan pemberi kerja

- Menjadi nilai acuan dalam pemberian insentif lainnya

- Besaran diformulasikan multitable

b. Tunjangan

Sebagai sebuah opsi atas penghasilan dikaitkan dengan suatu kondisi tertentu kriteria yang perlu dimasukkan dalam kategori ini adalah:

- Opsi penghasilan dikaitkan tunjangan yang berlaku umum

- Berlaku hanya pada beberapa pegawai dan tidak seluruhnya

c. Honorarium

Sebagai tambahan penghasilan sebagaimana tambahan pekerjaan diluar tugas utama kriteria untuk kategori ini adalah:

- Merupakan kompensasi dari tugas tambahan 
- Besaran tidak melebihi penghasilan utama

- Merupakan kompensasi dari tugas sekali, besaran mungkin tidak terkait dengan penghasilan utama

d. Fasilitas

Sebagai alat, bahan, akomodasi atau biaya tambahan yang diberikan guna mendukung pelaksanaan pekerjaan maka kriteria pada kategori ini adalah:

- Bukan tambahan penghasilan, namun penghindar pengurang gaji dan tunjangan

- Diberikan terkait dengan pelaksanaan tugas

\section{KESIMPULAN DAN REKOMENDASI}

\subsection{Kesimpulan}

Salah satu kunci keberhasilan sistem penggajian tunggal adalah dengan konsistensi kebijakan lain terkait dengan penghasilan pegawai. Secara alamiah, penghasilan bersifat variable menjadi salah satu konsekuensi atas pilihan sistem berbasis kinerja dalam penganggaran. Untuk itu, peran penting standar biaya perlu dijaga dengan konsistensi dalam perumusan kebijakan sebagai sebuah instrumen dari penganggaran berbasis kinerja, khususnya berkenaan dengan perumusan kebijakan honorarium dalam kerangka single remunerasi. Konsistensi dalam perumusan kebijakan tersebut akan meningkatkan kredibilitas rumusan yang menjadi arti pentingnya standar biaya dalam penjaga efisiensi pada level mikro. Kajian eksploratif ini mengusulkan pendekatan dalam perumusan kebijakan dimaksud guna mencapai tujuan konsistensi.

Honorarium dan remunerasi secara konsepsi berbeda berkenaan apakah kompensasi tersebut diperoleh atas tugas utama atau tugas tambahan. Dalam praktik, terjadi ambiguitas dalam penggunaannya istilah tersebut sebagai contoh penyebutan honor satpam pramubakti yang secara konsepsi seharusnya masuk sebagai gaji/remunerasi satpam pramubakti mengingat pekerjaan tersebut ada pekerjaan utama pada saat perikatan kontrak. Dengan demikian telah disampaikan cara-cara pemilhan antara honorarium dan remunerasi dengan empat pertanyaan, yakni:

a. apakah suatu pekerjaan merupakan pekerjaan utama atau pekerjaan tambahan

b. seberapa banyak waktu yang dibutuhkan dalam melaksanakan satu tugas

c. seberapa besar porsi penghasilan tambahan dibandingkan penghasilan utama (gaji dan tunjangan) yang diterima

d. adakah duplikasi pemberian kompensasi atas pekerjaan antara pekerjaan utama dan pekerjaan tambahan

selain empat pertanyaan tersebut sebagai alat untuk membedakan antara honorarium dan remunerasi, perlu juga pengelompokkan atas bentuk lain yang seolah-olah ada diantara keduanya. Dengan demikian pengelompokkan menjadi empat bagian yakni: Gaji, Tunjangan, Honorarium, dan Fasilitas. Keempat kelompok ini diupayakan guna 
menjaga konsistensi kebijakan yang diambil.

Sejalan dengan pengklasifikasian tersebut, besaran atas masing-masing klasifikasi perlu dijaga keseimbangannya. Bagaimana penghasilan tambahan dijaga agar tidak lebih besar dari penghasilan utama demi kepentingan organisasi secara keseluruhan.

\subsection{Rekomendasi}

Sebagai rekomendasi, terdapat tiga hal untuk dipertimbangkan:

a. kebijakan pengelompokan empat bagian terkait dengan penghasilan pegawai dapat digunakan sebagai landasan pengelompokan awal untuk kebijakan standar biaya.

b. Atas pengelompokan tersebut perlu penguatan kriteria sebagai ramburambu untuk melakukan formulasi besaran satuannya.

c. Pengelompokan diatas berkenaan dengan pekerja yang bekerja secara tetap pada satu pemberi kerja, atas satuan biaya penggunaan jasa tenaga kontrak perlu dilakukan kajian lanjut guna memperlakukan biaya yang tidak termasuk dalam kelompok dimaksud.

\section{DAFTAR PUSTAKA}

Asch, Beth J. (2005), The Economic Complexities of Incentive Reforms, High-Performance Government: Structure, Leadership, Inscentives, pp.309-379

Becker, Gary (1976). The Economic Approach to Human Behavior. Chicago: University of Chicago Press.

Lazear, Edward (1995). Personnel Economics. Cambridge: MIT Press.

Lazear, Edward (1997). Personnel Economics for Managers: New York: Wiley.

Prendergast, Canice (1999). The Provision of Incentives in Firms, Journal of Economic Literature, Vol.37, No.1 (Mar., 1999), pp.7-63

Sandel, Michael J. (2013), Market Reasoning as Moral Reasoning: Why Economists Should Re-engage with Political Philosophy. Journal of Economic Persctives-volume 27, Number 4-Fall 2013- Pages 121140

Bahan Bimtek Kebijakan Standar Biaya

PMK SBM tahun 2012-2016 